\title{
The effect of e-service quality, consumer trust and social media marketing on intention to use online transportation services
}

\author{
Zakiyah Zahara $^{a^{*}}$, Elimawaty Rombe ${ }^{a}$, Ngatimun Ngatimun ${ }^{b}$ and Judi Suharsono ${ }^{b}$
}

${ }^{a}$ Economic and Business Faculty Universitas Tadulako. Tondo Palu, Sulawesi Tengah, Indonesia ${ }^{b}$ Economic Faculty. Universitas Panca Marga Probolinggo Jawa Timur Indonesia

\section{H R O N I C L E}

Article history:

Received: February 20, 2021

Received in revised format: March

25,2021

Accepted: April 7, 2021

Available online: April 7, 2021

Keywords:

E-Service Quality

Consumer Trust

Social Media Marketing

Online Transportation Services

\section{A B S T R A C T}

\begin{abstract}
The aim of this study is to analyze the effect of e-service quality, consumer trust and social media marketing on intention to use online transportation services. The method used in this research is quantitative methods, data collection is executed by distributing questionnaires to consumers of Online Transportation Services. The population of this study is the Jabodetabek Online Transportation Services consumers whose numbers have not been identified with certainty. The questionnaire was distributed electronically using a simple random sampling technique. The results of the questionnaire returned were 180 respondents. Based on the results of data analysis, it is concluded that E-Service Quality has a significant effect on Intention to Use Online Transportation Services. Consumer Trust has no effect on Intention to Use Online Transportation Services. Social Media Marketing has a significant effect on Intention to Use Online Transportation Services.
\end{abstract}

(C) 2021 by the authors; licensee Growing Science, Canada.

\section{Introduction}

The presence of growing application technology on operating system-based smartphones has brought changes in all fields, including transportation. Online-based transportation applications have changed people's behavior in using transportation, customers no longer need to look for conventional transportation, but customers just need to make a reservation on the mobile application. Online transportation is preferred by customers since it offers convenience, lower costs, more guaranteed comfort and security and it is not surprising that many people are switching from conventional modes of transportation to online modes of transportation (Aziah \& Adawia, 2018). There are two online transportation providers that are quite well known in Indonesia today, namely Gojek and Grab. Currently, the development of online transportation in Indonesia has been so rapid, it can be seen from the number of users reaching 21.7 million people. This is based on the We Are Social 2020-Digital 2020 Indonesia report as of January 2020 (cnbcindonesia.com, 2020). Grab is one of the many Online Transportation Companies that provide "ride-sharing" and "ride-on-demand" services that use on-demand technology and services using web or mobile applications that connect drivers and passengers (Ackaradejruangsri, 2015). Smartphone application technology is able to answer people's needs to make it easier to access transportation modes in big cities, including in Jabotabek. Customers only need to use the cellphone after which the customer can immediately choose what mode of transportation will be present in front of their house (Putri et al., 2018).

Lately, the world has been quite shocked by the virus which has begun to spread to various regions and it has become a global pandemic. Indonesia, which is one of the countries affected by the COVID-19 virus, has had quite a big impact on all sectors, especially the economic sector. Various areas that are also affected by the COVID-19 virus have followed the instructions given by the central government to implement several activities that must be carried out by the community to prevent transmission of COVID-19, including work from home, learning from home, worshiping from home, even teaching and learning

* Corresponding author

E-mail address: ZakiyahZahara@untad.ac.id (Z.Zahara) 
activities also from home online, using masks, diligently washing hands using soap, and applying social distancing methods. The existence of Work From Home and social distancing hampers people's space in life because at Work From Home or WFH it will be more difficult for people to leave the house. To overcome this situation, people are starting to look to do online shopping because besides not having to leave the house, now many necessities of life are sold online. Therefore, the existence of the COVID-19 pandemic situation has also had an impact on the trend of consumer buying interest online and the intention to use online transportation services (Nguyen et al., 2020; Addo et al., 2020; Tran, 2020). The trend of buying interest online is usually carried out by young consumers because they are the ones who use online facilities to fulfill their needs. The majority of them are classified as active in using the internet in searching for products or services online through various platforms available in Indonesia, such as using online transportation services to find transportation services and can be used to order and deliver the goods they need. Even though the trend of buying interest online and the intention to use online transportation applications is usually dominated by teenagers but with conditions like now, with the COVID-19 the trend of online purchases is not only carried out by teenagers but also all age groups to meet their needs. Apart from the needs that must be met, the intention to use online transportation services can also be influenced by various factors, one of which is trust. Various studies conducted in the technology sector see the importance of trust as one of the factors that can improve customer relationships, increase credibility, and the perception of system security for customers (Liébana-Cabanillas et al., 2018). Manufacturers must understand various technological innovations that are considered beneficial for consumers and can increase trust in the system which in turn can influence the intention to use online transportation technology (Ehrenhard et al., 2017; Suhartanto et al., 2019).

Previous research has focused on various factors that can influence trust such as e-service quality (Al-Nasser et al., 2013). Eservice quality reflects an idea of online services offered by manufacturers so that customers can compare their expectations about existing service performance, when their expectations are met, customers feel confident in the capabilities of the producers (Tran \& Vu, 2019). Although various studies have found a positive effect of e-service quality on trust, research conducted by Shu-Chiung et al. (2011) found different results, the study explained that e-service quality has no effect on trust. Apart from e-service quality, well-packaged and targeted social media marketing can build consumer trust. Marketing through social media is considered by consumers to be more trustworthy than traditional elements of the promotional mix. Social media marketing may be better due to the fact that social media provides interactive communication, instant feedback, and more objective consumer-generated content (Tatar \& Eren-Erdogmus, 2016; Adriani \& Warmika, 2019). E-service quality and social media marketing are important elements to build positive feedback from users. However, how e-service quality and social media marketing can influence consumer confidence in the context of using online transportation still requires empirical validation. Therefore, this study attempts to address the research gap by examining the impact of e-service quality and social media marketing in generating trust and intention to use online transportation services during the COVID-19 pandemic.

\section{Method}

The method used in this research is quantitative methods, data collection is accomplished by distributing questionnaires to consumers of Online Transportation Services. The instrument used to measure all the variables of this study was adapted from (Bogler, 2001), with 5 items for each variable. Each closed question / statement item is given five answer options, namely: strongly agree (SS) score 5, agree (S) score 4, disagree (KS) score 3, disagree (TS) score 2, and strongly disagree (STS) score 1. The method for processing data is by using PLS and using the SmartPLS version 3.0 software as a tool. This study uses a questionnaire measuring tool given to respondents who have become the criteria. The questionnaire measurement scale uses a Likert scale, namely a scale of 1 - 5 such as; strongly disagree (1) to strongly agree (5) (Santosa, 2018). The research indicators for each variable such as e-service quality have seven items, adapted from (Pudjarti et al., 2019; Laurent, 2016). Social media marketing is measured by seven items adapted from (Smith, 2014). Meanwhile, trust is measured by five items adapted from (Chen \& Chang, 2012; Laroche et al., 2012). Also, intention to reuse services is measured by three items adapted from (Chiu et al., 2012). The population in this study is the Jabodetabek Online Transportation Services consumers whose numbers have not been identified with certainty. The questionnaire was distributed electronically using a simple random sampling technique. The results of the questionnaire returned were 180 respondents.

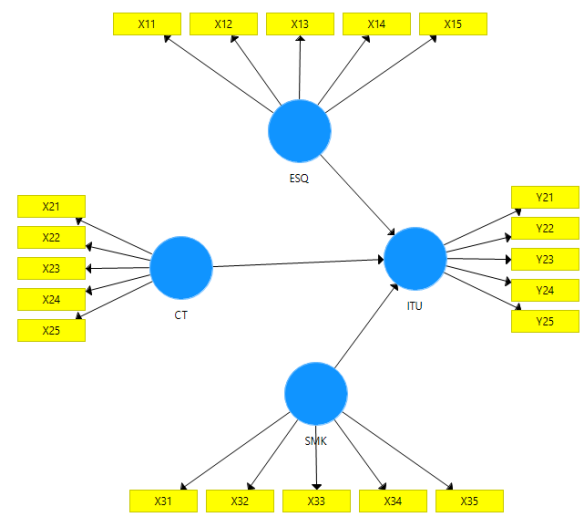

Fig. 1. Research Model 
Based on the theoretical review and previous research above, the research model as in Fig. 1 is compiled by the following research hypothesis:

$\mathrm{H}_{1}$ : E-Service Quality has a significant effect on Intention to Use Online Transportation Services.

$\mathrm{H}_{2}$ : Consumer Trust has a significant effect on Intention to Use Online Transportation Services.

$\mathrm{H}_{3}$ : Social Media Marketing has a significant effect on Intention to Use Online Transportation Services.

\section{Results and discussion}

Fig. 2 demonstrate the summary of the personal characteristics of the participants.

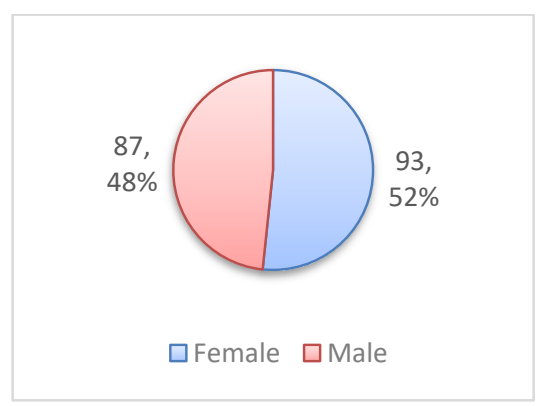

Gender
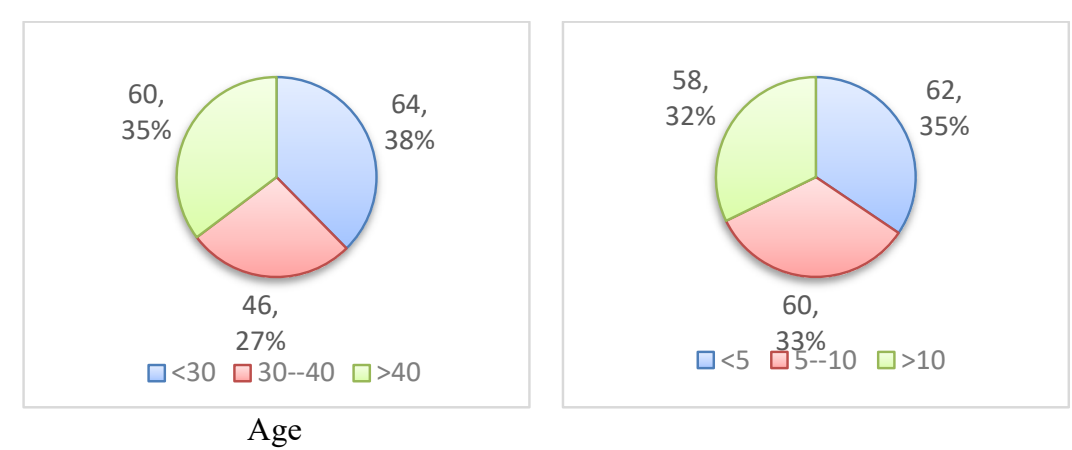

Fig. 2. Personal characteristics of the participants

Test Results of the Validity and Reliability of Research Indicators

The testing phase of the measurement model includes testing for convergent validity, discriminant validity and composite reliability. The results of the PLS analysis can be used to test the research hypothesis if all indicators in the PLS model have met the requirements of convergent validity, discriminant validity and reliability testing. Convergent Validity Testing Convergent validity test is done by looking at the loading factor value of each indicator against the construct. In most references, a factor weight of 0.5 or more is considered to have sufficiently strong validation to explain latent constructs (Chin, 1998; Hair et al., 2010; Ghozali, 2014; Azizah \& Adawia, 2018; Putrianti \& Semuel, 2018). In this study, the minimum limit for the accepted loading factor is 0.5 , provided that the AVE value of each construct is $>0.5$ (Ghozali, 2014).

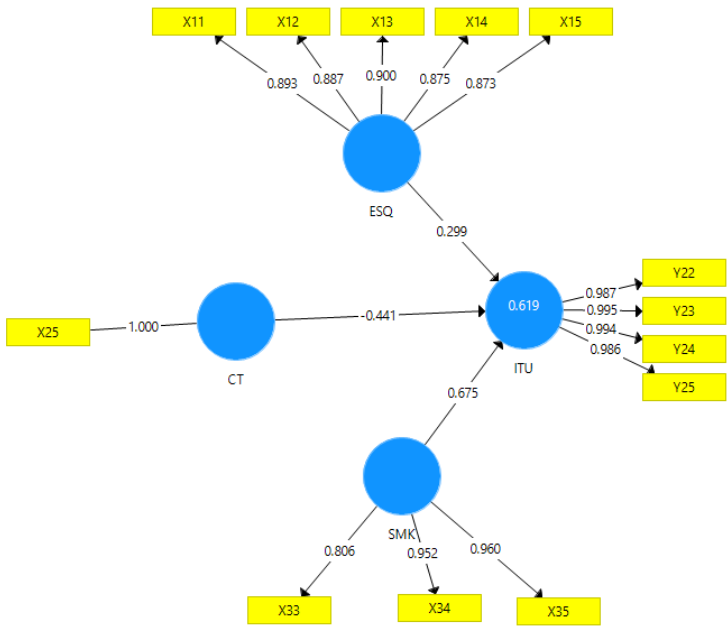

The results of coefficients

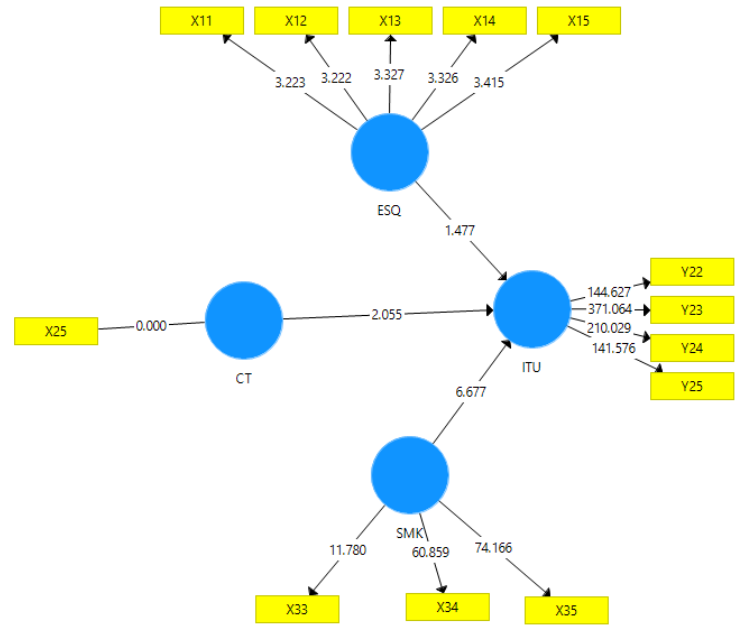

The results of statistical test

Fig. 3. Model valid

Based on the estimation results of the PLS model in the image above, all indicators have a loading factor value above 0.5 so that the model has met the convergent validity requirements. Apart from looking at the loading factor value of each indicator, convergent validity was also assessed from the AVE value of each construct. The AVE value for each construct of this study is above 0.5 . So, the convergent validity of this research model has met the requirements. The value of loadings, Cronbach's alpha, composite reliability and AVE for each complete construct can be seen in Table 1 . 
Table 1

Cronbach's Alpha, Composite Reliability, and Average Variance Extracted (AVE)

\begin{tabular}{ccccc}
\hline & Cronbach's Alpha & rho_A & Composite Reliability & Average Variance Extracted (AVE) \\
\hline CT & 1.000 & 1.000 & 1.000 & 1.000 \\
ESQ & 0.933 & 0.968 & 0.948 & 0.784 \\
ITU & 0.994 & 0.995 & 0.995 & 0.981 \\
SMK & 0.898 & 0.985 & 0.934 & 0.826 \\
\hline
\end{tabular}

\section{Construction Reliability Testing}

Construct reliability can be assessed from the Cronbach's alpha value and the composite reliability of each construct. The recommended composite reliability and Cronbach's alpha value is more than 0.7 (Ghozali, 2014). The reliability test results in Table 2 above show that all constructs have composite reliability and Cronbach's alpha values are greater than 0.7 ( $>0.7)$. In conclusion, all constructs have met the required reliability.

\section{Discriminant Validity Testing}

Discriminant validity is done to ensure that each concept of each latent variable is different from other latent variables. The model has good discriminant validity if the AVE square value of each exogenous construct (the value on the diagonal) exceeds the correlation between this construct and other constructs (values below the diagonal) (Ghozali, 2014). The results of discriminant validity testing using the AVE square value, namely by looking at the Fornell-Larcker Criterion Value are obtained in Table 2 as follows:

\section{Table 2}

Item Loading and Cross-Loading

\begin{tabular}{lllll}
\hline & CT & ESQ & ITU & \\
\hline X11 & & 0.893 & & \\
X12 & & 0.887 & & \\
X13 & & 0.900 & & 0.806 \\
X14 & & 0.875 & \\
X15 & 1.000 & 0.873 & & 0.952 \\
X25 & & & & 0.960 \\
X33 & & & 0.987 & 0.995 \\
X34 & & 0.994 & 0.986 \\
X35 & & & & \\
Y22 & & & \\
Y23 & & & \\
Y25 & & & \\
\hline
\end{tabular}

The results of the discriminant validity test in Table 2 above show that all constructs have a square root value of AVE above the correlation value with other latent constructs (through the Fornell-Larcker criteria) so that it can be concluded that the model has met discriminant validity.

Table 3

Discriminant Validity

\begin{tabular}{|c|c|c|c|c|}
\hline & CT & ESQ & ITU & SMK \\
\hline CT & 1.000 & & & \\
\hline ESQ & 0.614 & 0.886 & & \\
\hline ITU & -0.233 & 0.133 & 0.991 & \\
\hline SMK & 0.036 & 0.156 & 0.705 & 0.909 \\
\hline
\end{tabular}

\section{Hypothesis test}

Hypothesis testing in PLS is also known as the inner model test. This test includes a significance test for direct and indirect effects as well as a measurement of the magnitude of the influence of exogenous variables on endogenous variables. To determine the effect of transformational leadership and transactional leadership on teacher job perceptions and teacher job satisfaction, a direct and indirect effect test is needed. The effect test was performed using the t-statistic test in the partial least squared (PLS) analysis model using the SmartPLS 3.0 software. With the bootstrapping technique, the R Square value and significance test values are obtained as shown in the table below:

Table 4

Nilai $R$ Square

\begin{tabular}{ccc}
\hline & $R$ Square & $R$ Square Adjusted \\
\hline$I T U$ & 0.619 & 0.605 \\
\hline
\end{tabular}


Based on Table 4 above, the R Square value is 0.619 which means that the Intention to Use Online Transportation Services variable can be explained by the E-Service Quality, Consumer Trust on and Social Media Marketing variables by $61.9 \%$, while the remaining $38.1 \%$ is explained by other variables. which was not discussed in this study.

Table 5

\begin{tabular}{cccccc} 
Hypotheses Testing & & & & \\
\hline & Original Sample (O) & Sample Mean $(\mathrm{M})$ & Standard Deviation $(\mathrm{STDEV})$ & T Statistics $(|\mathrm{O} / \mathrm{STDEV}|)$ & P Values \\
\hline $\mathrm{CT} \rightarrow$ ITU & -0.441 & -0.420 & 0.215 & 2.055 \\
$\mathrm{ESQ} \rightarrow$ ITU & 0.299 & 0.268 & 0.202 & 1.477 \\
$\mathrm{SMK} \rightarrow$ ITU & 0.675 & 0.717 & 0.101 & 0.140 & 6.677 \\
\hline
\end{tabular}

Meanwhile, Table 5 shows the T Statistics and P-Values which show the influence between the research variables that have been mentioned.

\section{Relationship between E-Service Quality and Intention to Use Online Transportation Services}

Based on the results of the analysis in Table 5, it is obtained T Statistics of 2.055 $>1.96$ and P-Values of $0.040<0.050$ so that it can be concluded that $\mathrm{H} 1$ is accepted, E-Service Quality has a significant effect on Intention to Use Online Transportation Services. An increase in E-Service Quality variables will be followed by an increase in Intention to Use Online Transportation Services and a decrease in the E-Service Quality variable will be followed by a decrease in Intention to Use Online Transportation Services

\section{Relation between consumer Trust and Intention to Use Online Transportation Services}

Based on the results of the analysis in table 6, it is found that T Statistics is $1.477<1.96$ and P-Values $0.140>0.050$ so it can be concluded that $\mathrm{H} 2$ is rejected. Consumer Trust has no effect on Intention to Use Online Transportation Services. The increase in the Consumer Trust variable did not affect the Intention to Use Online Transportation Services variable and the decrease in the Consumer Trust variable did not affect the Intention to Use Online Transportation Services variable

\section{Relationship between Social Media Marketing and Intention to Use Online Transportation Services}

Based on the results of the analysis in table 6, it is obtained T Statistics of 6,677 $>1.96$ and P-Values of $0.000<0.050$ so that it can be concluded that H3 is accepted, Social Media Marketing has a significant effect on Intention to Use Online Transportation Services. Consumer Trust Consumer Trust. Increasing the Social Media Marketing variable will increase the Intention to Use Online Transportation Services variable and decrease the E-Service Quality variable will reduce the Intention to Use Online Transportation Services variable. It can be concluded that hypothesis 1 explains that with the use of e-service quality in online-based applications (online transportation) and provided to consumers well, this will create and build good trust in consumers / users. This result is in line with previous research (Tran and Vu, 2019). This happens because e-service quality is considered as an important strategy to build trust and achieve success in a business, even e-service quality is considered more important than the price strategy. The success of e-service quality reflects how customer expectations are comparable to the performance of the services provided (Tran and Vu, 2019). Therefore, by using a good e-service quality strategy and the service is considered appropriate or even exceeds the expectations of consumers or users, they will build trust in the company.

It can be concluded that hypothesis 2 explains that using effective social media marketing can create and build consumer / user trust. These results are in line with previous studies (Irshad et al., 2020). This happens because with the emergence of marketing carried out through social media, enabling consumers to find and get positive information and the information they need, this can help consumers to build their trust (Irshad et al., 2020). This indicates that using marketing through social media by providing clear information and according to the needs of consumers, this strategy can encourage trust for them. Not only that, social media marketing can also help consumers easily find the information they need.

Hypothesis 3 explains that trust has a positive effect on the intention to reuse it explains that the existence of built-in trust in consumers / users, this can encourage their intention to reuse an application. These results are in line with previous studies (Giantari et al., 2013). This happens because with the formation of consumer trust in an online vendor, meaning that consumers are confident in the integrity of the vendor, consumers are also confident that the vendor will act ethically, fulfill his promises, make a good deal, and tell the truth (Hallikainen \& Laentuken, 2018). So that consumers who are confident in the ability of the vendor feel that the quality and expectations they have will be fulfilled by repurchasing the product. For this reason, the formation of trust can encourage consumers to buy back.

This suggests that trust is the perfect link in the indirect relationship between e-service quality and intention to reuse. Providing good quality e-service will create an intention to reuse the service if it is supported by confidence in the consumer or user. The results of this study are in line with previous research (Wuisan et al., 2020; Lien et al., 2015) which shows the better the 
ability of the company to handle problems faced by customers and provide good service to customers, this will increase customer confidence in the company which can trigger repurchase interest. This indicates that with the use of good information, making the application as easy to use as possible, and the existence of security protection for customers will build their trust that will ultimately intend to reuse the services offered by the company. This suggests that trust is the perfect link in the indirect relationship between social media marketing and reuse intent. The use of marketing that is carried out through social media and carried out with the right target will create an intention to reuse the service if it is supported by confidence in the consumer or user. The results of this study are in line with previous research (Tong, 2020) which shows that using effective marketing through social media will build consumer intention to buy back through the trust that consumers have. This is because consumers are accustomed to shopping and looking for various information through social media, so that by providing campaigns or marketing through social media is considered an effective strategy in building trust as well as building consumer intention to buy or reuse existing services.

\section{Conclusion}

Based on the results of data analysis, it is concluded that E-Service Quality has a significant effect on Intention to Use Online Transportation Services. Consumer Trust has no effect on Intention to Use Online Transportation Services. Social Media Marketing has a significant effect on Intention to Use Online Transportation Services. This study concludes that e-service quality and social media marketing have an effect on consumer trust, which in turn, this trust can encourage consumer or user intention to reuse online transportation services. Trust was also found to be a good mediator or liaison between the influence of e-service quality and social media marketing on intentions to reuse online transportation services. Advice that can be given, the management of online transportation companies should always pay attention and always improve the quality of their services electronically in a continuous manner provide accurate and easy to understand information, besides that the company can continue to update their service application so that consumers can use the application more easily, including the security of personal data which the company must always pay attention to. The use of marketing through social media is also important for companies because by using this strategy the information they want to provide to consumers will arrive effectively and efficiently, consumers will also find it easier to find the type of information they want. By paying attention to this strategy, companies can build consumer trust, because trust is a very important factor in the business world. When this trust has been formed, what else during the Covid-19 pandemic, which occurs when customers find it difficult to leave, by building their trust through providing information that can illustrate that this application can help consumers to order food, goods and medicines drugs that can ultimately encourage consumers to buy or reuse the service. Like other studies, current research has several limitations which will provide opportunities for future research. First, this study considers the measurement of service quality online, while the concept of online transportation services provided can be done both online and offline. For this reason, future research can use the concept of online and offline services in order to measure more clearly how their level of trust in the services provided by the company. The study of social media marketing is influenced by reference theory and empirical results from other studies. In future research, it will be better to develop alternative models and strategies to see which social media marketing model is most appropriate. The use of different social media platforms can also be another influence on consumer responses and behavior. For this reason, in further research, which social media platform should be used in the research is determined first, this is to be able to measure the level of marketing effectiveness carried out and the level of user involvement on the social media platform. In addition, regarding the sample, it would be interesting if further research targeted a larger sample and made comparisons.

\section{References}

Ackaradejruangsri, P. (2015). Insights on GrabTaxi: An alternative ride service in Thailand. Review of Integrative Business and Economics Research, 4(3), 49.

Addo, P. C., Jiaming, F., Kulbo, N. B., \& Liangqiang, L. (2020). COVID-19: fear appeal favoring purchase behavior towards personal protective equipment. The Service Industries Journal, 40(7-8), 471-490.

Adriani, N. N., \& Warmika, I. G. K. (2019). Pengaruh Kualitas Pelayanan Dan Persepsi Nilai Terhadap Kepuasan Dan Niat Menggunakan Kembali. E-Jurnal Manajemen, 8(4), 1956-1984.

Al-Nasser, M., Yusoff, R. Z., Islam, R., \& ALNasser, A. (2013). E-Service Quality And Its Effect On Consumers Perceptions Trust. American Journal of Economics and Business Administration, 5(2), 47.

Azizah, A., \& Adawia, P. R. (2018). Analisis perkembangan industri transportasi online di era inovasi disruptif (Studi Kasus PT Gojek Indonesia). Cakrawala-Jurnal Humaniora, 18(2), 149-156.

Chiu, C.M., Hsu, M.H., Lai, H., and Chang, C.M. (2012). Re-Examining The Influence of Trust on Online Repeat Purchase Intention: The Moderating Role Of Habit And Its Antecedents. Decision Support Systems, 53(4), 835-845.

Cnbcindonesia. (2020). 21,7 Juta Masyarakat Indonesia Pakai Transportasi Online. Retrieved march 06, 2021, from https:/www.cnbcindonesia.com/tech/20200317150135-37-145529/217-juta-masyarakat-indonesia-pakai-transportasionline

Ehrenhard, M., Wijnhoven, F., van den Broek, T., \& Stagno, M. Z. (2017). Unlocking how start-ups create business value with mobile applications: Development of an App-enabled Business Innovation Cycle. Technological forecasting and social change, 115, 26-36. 
Giantari, I. G. A. K., Zain, D., Rahayu, M., \& Solimun, M. (2013). The role of perceived behavioral control and trust as mediator of experience on online purchasing intentions relationship a study on youths in denpasar city (Indonesia). International Journal of Business and Management Invention, 2(1), 30-38.

Hair, J. F., Hult, G. T. M., Ringle, C. M., \& Sarstedt, M. (2014). A Primer on Partial Least Square Structural Equation Modeling (PLS-SEM). SAGE Publications. London.

Hajli, N. (2015). Social commerce constructs and consumer's intention to buy. International Journal of Information Management, 35(2), 183-191

Hallikainen, H., \& Laukkanen, T. (2018). National culture and consumer trust in e-commerce. International Journal of Information Management, 38(1), 97-106.

Hayashi, F., \& Bradford, T. (2014). Mobile payments: Merchants’ perspectives. Economic Review, 99, 5-30.

Irshad, M., Ahmad, M. S., \& Malik, O. F. (2020). Understanding consumers' trust in social media marketing environment. International Journal of Retail \& Distribution Management. 48(11), 1195-1212.

Jeon, M. M., \& Jeong, M. (2017). Customers' perceived website service quality and its effects on e-loyalty. International Journal of Contemporary Hospitality Management, 29(1), 438-457.

Laroche, M., Habibi, M. R., Richard, M. O., \& Sankaranarayanan, R. (2012). The effects of social media based brand communities on brand community markers, value creation practices, brand trust and brand loyalty. Computers in Human Behavior, 28(5), 1755-1767.

Laurent, F. (2016). Pengaruh E-Service Quality Terhadap Loyalitas Pelanggan Go-Jek Melalui Kepuasan Pelanggan. AGORA, 4(2), 95-100.

Liébana-Cabanillas, F., Marinkovic, V., de Luna, I. R., \& Kalinic, Z. (2018). Predicting the determinants of mobile payment acceptance: A hybrid SEM-neural network approach. Technological Forecasting and Social Change, 129, $117-130$.

Lien, C.-H., Wen, M.-J., Huang, L.-C., \& Wu, K.-L. (2015). Online hotel booking: The effects of brand image, price, trust and value on purchase intentions. Asia Pacific Management Review, 20(4), 210-218

Lu, B., Fan, W., \& Zhou, M. (2016). Social presence, trust, and social commerce purchase intention: An empirical research. Computers in Human Behavior, 56, 225-237.

Manzoor, U., Baig, S. A., Hashim, M., \& Sami, A. (2020). Impact of Social Media Marketing on Consumer's Purchase Intentions: The Mediating role of Customer Trust. International

Nguyen, H. V., Tran, H. X., Van Huy, L., Nguyen, X. N., Do, M. T., \& Nguyen, N. (2020). Online Book Shopping in Vietnam: The Impact of the COVID-19 Pandemic Situation. Publishing Research Quarterly, 36, 437-445.

Park, J., Lee, J., Lee, H., \& Truex, D. (2012). Exploring the impact of communication effectiveness on service quality, trust and relationship commitment in IT services. International Journal of Information Management, 32(5), 459-468.

Pudjarti, S., Nurchayati, N., \& Putranti, H. R. D. (2019). Hubungan E-Service Quality Dan E-Loyalty Dengan E-Satisfaction Pada Konsumen Go-Jek dan Grab di Kota Semarang. Sosiohumaniora - Jurnal Ilmu-Ilmu Sosial Dan Humaniora, 21(3), 237-246.

Putri, Y. A., Wahab, Z., \& Shihab, M. S. (2018). The Effect of Service Quality and Brand Trust on Loyalty and the Intervening role of Customer Satisfaction in Transportation Online. International Journal of Scientific and Research Publications, $8(7), 369-376$.

Putrianti, A. S., \& Semuel, H. (2018). The Analysis of E-service Quality, Customer Trust, Perceived Value, and Behavioral Intention on Online Transportation in Surabaya. Petra International Journal of Business Studies, 1(1), 1-10.

Santosa, P. I. (2018). Metode Penelitian Kuantitatif - Pengembangan Hipotesis dan Pengujiannya Menggunakan SmartPLS. Yogyakarta: Penerbit ANDI.

Shu-Chiung, L., Sheng-Wei, L., Chin-Yen, T., Ying-Ping, Y., \& Pei-Hwa, Y. (2011). How E-SERVQUAL affects customer's online purchase intention through cross-culture comparison. Proceedings of the Technology Innovation and Industrial Management, 1-13.

Smith, T. M. (2014). Consumer Perceptions of a Brand's Social Media Marketing.

Suhartanto, D., Helmi Ali, M., Tan, K. H., Sjahroeddin, F., \& Kusdibyo, L. (2019). Loyalty toward online food delivery service: the role of e-service quality and food quality. Journal of Foodservice Business Research, 22(1), 81-97.

Tatar, Ş. B., \& Eren-Erdoğmuş, İ. (2016). The effect of social media marketing on brand trust and brand loyalty for hotels. Information Technology \& Tourism, 16(3), 249-263.

Tong, T. K. P. B. (2020). Analisa Pengaruh Social Media Marketing Terhadap Repurchase Intention Melalui Brand Trust Sebagai Variabel Mediasi Pada Instagram Adidas Indonesia Di Surabaya. Jurnal Strategi Pemasaran, 7(1), 1-10.

Tran, V. (2020). The relationship among performance risk, safety risk, social risk, psychological risk, satisfaction and intentions to use grab service in Vietnam amid Covid-19 crisis. Journal of Project Management, 5(4), 201-210.

Tran, V. D., \& Vu, Q. H. (2019). Inspecting the relationship among E-service quality, E-trust, E-customer satisfaction and behavioral intentions of online shopping customers. Global Business \& Finance Review (GBFR), 24(3), 29-42.

Wuisan, D. S., Candra, D., Tanaya, M. A., Natalia, V., \& Bernarto, I. (2020). Pengaruh Website Design Quality dan E-Service Quality Terhadap Repurchase Intention Sociolla E-Trust Sebagai Variabel Mediasi. 
(C) 2021 by the authors; licensee Growing Science, Canada. This is an open access article distributed under the terms and conditions of the Creative Commons Attribution (CC-BY) license (http://creativecommons.org/licenses/by/4.0/). 